\title{
CERITA DALAM RANGKA MENINGKATKAN TOLERANSI DAN KEBHINEKAAN
}

\author{
Stories In Order To Increase Tolerance And Improvement
}

\author{
Sidik Nuryanto
}

PG PAUD, Universitas Muhamadiyah Ponorogo

Email Korespondensi : nuryantosidik@gmail.com

\begin{abstract}
ABSTRAK
Indonesia adalah negara yang majemuk dengan berbagai keberagaman meliputi agama, suku, budaya, ras, bahasa dan sebagainya. Dengan keberagaman rawan adanya konflik karena perbedaan dan sikap intoleransi. CERITA dapat sebagai solusinya yaitu program yang dikeharkan oleh The Habibie Center. Adapun kepanjangan Community Empowerment for Raising Inclusivity and Trust through Technology Application. Program pengabdian masyarakat ini dilakukan dengan metode pelatihan bercerita yang bermuatan keberagaman dan toleransi. Luarannya adalah peserta dapat membuat cerita dan dunggah pada peta cerita.

Kata kunci : CERITA, Toleransi dan Keberagaman, Peta Cerita
\end{abstract}

\section{ABSTRACT}

Indonesia is a diverse country with various diversity including religion, ethnicity, culture, race, language and etc. With diversity prone to conflict because of differences and attitudes of intolerance. CERITA become the solution. That program was issued by The Habibie Center. cerita stands for Community Empowerment for Raising Inclusivity and Trust through Technology Application. This community service program is held with a storytelling training method. The participant's story contains of diversity and tolerance. The output is participants can create stories and upload them on story maps.

Keywords: Stories, Tolerance and Diversity, Story Maps

\section{PENDAHULUAN}

Indonesia adalah negara yang subur dengan berbagai kekayaan alam yang tersebar mulai dari darat, laut hingga udara. Kekayaan alam yang luar biasa tersebut memunculkan sebutan negara Indonesia itu "gemah ripah loh jinawi". Disamping kekayaan alam yang melimpah, Indonesia juga memiliki aset keberagaman yang kaya. Seperti halnya keberagaman agama, suku, budaya, bahasa, ras, dan lainnya. Tercatat tahun 2017 Indonesia memiliki 34 Propinsi yang tersebar dari Sumatera hingga Papua.

Dengan jumlah penduduk 237 juta jiwa di tahun 2010, Indonesia memiliki 1331 kategori suku. Sejumlah 1331 kategori itu merupakan kode untuk nama suku, nama lain/alias suatu suku, nama subsuku, bahkan nama sub dari subsuku. Keberagaman lain ditunjukkan dengan jumlah bahasa daerah yang mencapai 1158 bahasa daerah (https://www.bps.go.id).

Keberagaman di Indonesia bukan menjadi masalah untuk dipertentangkan siapa yang paling benar maupun yang paling unggul. Namun kesemuanya saling mendukung dan menghargai satu sama lain. Sehingga tercipta suasana saling toleransi, menghargai dan tidak menjatuhkan. Hal tersebut telah didukung oleh semboyan bhinneka tunggal ika yang artinya meskipun 
berbeda beda namun tetap satu juga. Iklim

Indonesia yang majemuk namun harmonis dan rukun membuat iri negara-negara lain, sehingga terkadang dari musuh untuk memecah belah persatuan dan kesatuan Indonesia. Seperti halnya yang terjadi pada akhir 2016 banyak dijumpai kasus yang berhubungan dengan sara seperti pembakaran tempat ibadah, penistaan agama, melarang pendirian rumah ibadah, serta menjelekkan kelompok lain.

Perkara yang berhubungan dengan isu keberagaman sempat memanas di akhir tahun 2016 yaitu kasus Ahok (Basuki Tjahaya Purnama). Gubernur DKI Jakarta periode tersebut dianggap telah melakukan penistaan agama Islam. Kejadian bermula ketika pidatonya di Kepulauan Seribu, 27 September 2016 yang mengutip Surat Al Maidah ayat 51 yang konteksnya memang berdekatan dengan pemilihan Gubernur selanjutnya. Ahok yang berkeyakinan Kristen menyinggung Surat Al Quran yang notabene bukan kapasitas dirinya untuk membahas kitab suci tersebut. Dalam surat Al Maidah ayat 51 berisi perintah kepada pemeluk agama Islam untuk memilih pemimpin yang juga beragama Islam.

Kasus penistaan agama Islam tersebut memicu kemarahan umat Islam seluruh Indonesia karena aparat penegak hukum dinilai lamban untuk mengusut perkara. Berbagai laporan baik langsung, adanya petisi, maupun pemberitaan di media yang begitu ramai, namun tidak segera ditanggapi oleh pihak kepolisian. Makanya muncul aksi demonstrasi berskala besar di Jakarta yang diberi nama Aksi Bela Islam. Tuntutan aksi tersebut menuntut pemerintah dan aparat penengak hukum untuk menangkap dan mempenjarakan pelaku penista agama.

Kasus penistaan apabila tidak segera
(Halaman 29-36)

ditangani secara serius maka akan memunculkan kasus serupa yang lebih parah. Potensi itu sangat besar karena Indonesia adalah negara yang majemuk dengan berbagai keberagaman. Apabila sikap toleransi dalam kebergaman itu sudah mulai luntur maka peperangan sesama warga Indonesia bakal terjadi. Konflik yang mengatas namakan perbedaan/konflik Sara juga pernah terjadi dalam skala besar di Indonesia. Seperti peperangan antara Suku Sampit dan Madura (2001), konflik antara etnis pribumi dan etnis Tionghoa (1998), Konflik Antar Agama di Ambon (1999), Konflik Antar Golongan Agama (Ahmadiyah dan Syiah) (2000), serta Konflik Antar Golongan dan Pemerintah (GAM, RMS, dan OPM).

Belakangan ini kasus-kasus yang dikhawatirkan memecah kebhinekaan diantaranya sikap intoleransi sesama warga Indonesia. Oleh Komnas HAM Jayadi Damalik selaku koordinator desk Kebebasan Beragama dan Berkeyakinan (KBB) menyimpulkan bahwa di tahun 2016 telah terjadi peningkatan kasus intoleransi. Sebelumnya pada tahun 2014 mencatat ada 74 kasus, kemudian menjadi 87 pada tahun 2015. Adapun di tahun 2016 meningkat tajam menjadi 100 kasus. Bentuk kasusnya meliputi melarang aktivitas keagamaan, merusak rumah ibadah diskriminasi atas dasar keyakinan atau agama, intimidasi, dan pemaksaan keyakinan.

CERITA memiliki kepanjangan Community Empowerment for Raising Inclusivity and Trust through Technology Application. Program yang dibawah naungan The Habibie Center merupakan sebuah program untuk inklusivitas yang menggabungkan storytelling, transformasi konflik dan penggunaan aplikasi digital. 
Konten program adalah mengajak kaum muda untuk saling menebarkan isu toleransi dan keberagaman sehingga dapat menurunkan konflik yang berbau sara. Seperti yang terjadi saat ini bahwa berita tentang sara seperti artikel, foto maupun video yang menebarkan kebencian dengan mudah tersebar lewat media masa. Ternyata berita yang disebarkan belum tentu kebenarannya. Makanya dengan program ini diharapakan dapat menangkal isu sara yang berbau kebencian dan menebar semangat toleransi.

CERITA dilaksanakan dengan pelatihan yang terbagi dalam beberapa sesi seperti game, diskusi kelompok, problem solving, hingga penciptaan cerita tentang keberagaman. Pesan dan makna dari setiap sesi pelatihan selalu menghadirkan nilai saling menghargai, toleransi dan tidak mudah tersulut berita hoax. Puncak dari pelatihan cerita adalah tercipta cerita pribadi yang memiliki konten keberagaman dan semangat toleransi. Adapun selanjutnya cerita tersebut akan disebarkan dalam sebuah media digital ponsel sehingga dapat menjadi penangkal berita ujaran intoleransi.

Dalam akun instagram resmi The Habibie Center bahwa CERITA bertujuan untuk mengumpulkan anak muda Indonesia yang aktif yang berasal dari beragam latar belakang agama dan budaya, untuk memfasilitasi dialog dan berbagi cerita tentang pengalaman kerukunan dan keberagaman mereka yang akan mudah dimuat dalam sebuah aplikasi digital ponsel. Melalui proses pembelajaran dan pemahaman perjalanan hidup satu sama lain diharapkan kita dapat memperkuat Bhinneka Tunggal Ika dan dapat menciptakan konten positif untuk melawan informasi palsu serta pesan-pesan yang dapatmemicu ketegangan
(Halaman 29-36)

sosial dan kekerasan atas perbedaan agama dan budaya.

\section{METODE}

Kegiatan ini diikuti oleh 20 peserta yang melek memiliki jiwa sosial, melek teknologi, dan tertarik dengan isu keberagaman. Peserta pelatihan harus beragam seperti agama/keyakinan, suku, pekerjaan, jenis kelamin, tingkat pendidikan, ras dan lainnya. Adapun luarannya adalah terbuatnya cerita tentang keberagaman dan toleransi yang nantinya siap untuk dipublikasikan.

Tahapan metode dalam kegiatan ini adalah:

- Melakukan penjaringan peserta secara online dengan memasukkan unsur keberagaman.

- Memilih sejumlah 20 peserta dengan berbagai keberagaman

- Melakukan pelatihan dengan kombinasi teknik seperti ceramah, tanya jawab, permainan, diskusi, demonstrasi, simulasi, dan praktek bercerita.

- Menentukan pasangan bercerita yang terdiri dua orang yang memiliki perbedaan.

- Setiap pasangan bertugas untuk membuat cerita tentang pribadinya masing-masing dan membuat cerita bersama dengan memuat unsur cerita pribadi tadi.

- Merekam cerita setiap pasangan/ peserta.

- Mempublikasikan melalui media online/internet.

\section{HASIL DAN PEMBAHASAN}

Kegiatan pengabdian masyarakat ini dilakukan dalam beberapa kegiataan yaitu permainan, dialog perbedaan dan pembuatan cerita.

1. Permainan (Aku, Kamu dan Kita) 
Tujuannya untuk saling mengenal sesame peserta dan menghargai perbedaan.

\section{Bentuk Kegiatan:}

a. Membuat peta di ruangan yang luas, dengan memberi tanda utara, timur, selatan dan barat. Semua peserta berada ditengah lingkaran dengan asumsi berada di kota pelatihan berlangsung.

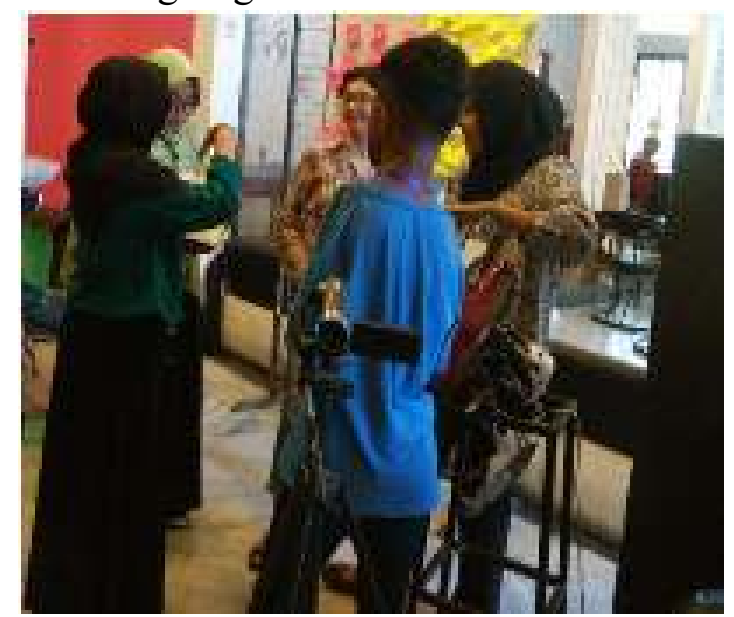

Gambar 1. Permainan Perkenalan

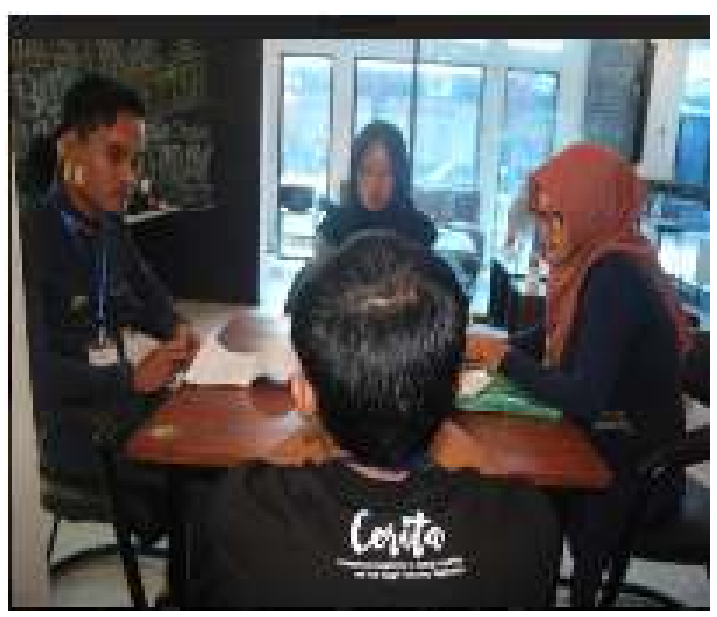

Gambar 2. Dialog Perbedaan

\section{Penjelasan Peran Dalam Diskusi}

Peran Negatif Dalam Diskusi

1.Bully. Menindas anggota kelompok lainnya dengan cara meneriaki dan bersikap sarkastik.

2.Pengeluh. Terus menerus menyatakan ketidaksenangannya terhadap apa yang

Sidik N., CERITA DALAM RANGKA... dikerjakan, atau mengatakan sesuatu yang tidak penting

3.Pemblokir. Menghambat kemajuan kelompok dalam berdiskusi dengan mengatakan hal-hal seperti: "Itu sih udah jelas", "Terus apa gunanya?", atau "Semua juga udah tahu!"

4.Pendominasi. Mengambil alih kelompok dan tidak membiarkan anggota lain untuk berbicara atau membuat keputusan.

5.Penyendiri. Hanya berbicara dengan satu orang tertentu, bukan dengan seluruh anggota kelompok.

6.Pemimpi. Tidak ambil bagian dan tidak tertarik untuk ikut dalam diskusi.

\section{Peran Positif dalam diskusi}

1.Penggagas. Menggerakkan diskusi dengan ide-ide yang baru.

2.Penanya. Mengajukan pertanyaan yang membantu kelompok untuk berpikir dan mengeksplorasi.

3.Penjelas. Mengulang dan menjelaskan ide kepada kelompok

4.Organisator. Merencanakan bagaimana kelompok akan bekerja

5.Penyemangat. Menyemangati anggota kelompok dengan cara mendengar, memberi masukan, dan mendukung.

6.Penolong. Membantu kelompok dengan memastikan semuanya ikut berperan aktif dan membantu anggota untuk saling melihat sudut pandang satu sama lain.

Dialog merupakan proses yang selalu terjadi dalam kehidupan manusia. Makanya dituntut untuk selalu berpikiran positif dan berprasangka baik. Oleh Mukti Ali (1975) mendelaskan bahwa dialog adalah suatu proses dimana individu dan kelompok belajar untuk menghilangkan saling curiga dan saling takut dan berusaha untuk 
(e-ISSN: 2579-9797)

Diterima: Agustus 2018

Dipublikasikan: Desember 2018

mengembangkan hubungan-hubungan yang

didasarkan kepada saling percaya mempercayai. Dialog adalah merupakan hubungan yang sejuk dan ditunjukan untuk hidup bersama, berbuat bersama dan mendirikan dunia baru bersama.

Selain dialog menurut buku toleransi di daerah rawan konflik (2016) Organisasi kemasyarakatan nasional seperti Nahdlatul Ulama dan Muhammadiyah cukup memberikan warna kerukunan dan toleransi kehidupan keagamaan seperti di Kota Padang. Makanya tokoh tersebut sering dilibatkan dalam berbagai pertemuan adat/ kelompok.

\section{Membuat Cerita}

\section{A. Langkah Bercerita yang baik}

1) Bersifat personal/ pribadi

Cerita merupakan pengalaman pribadi yang dilakukan/ dialami oleh pencerita. Bisa jadi cerita tesebut belum pernah disampaikan di forum lainnya. Menyampaiakan cerita pribadi lebih bermakna dan berkesan karena ia mengalami langsung sehingga emosi/ perasaan dalam penyampaiannya akan ikut terbawa. Mengingat forum tersebut eksklusif dan isu yang dibahas adalah keberagaman dan toleransi makanya sangat tepat untuk menyampaikannya.

2) Tema cerita meliputi:

Keluarga dan masa kecil. seperti: orangtua dan keluarga, pengalaman bertumbuh dewasa, komunitas, tokoh panutan, sekolah.

Pilihan hidup: Sekolah, karir, pasangan/ keluarga, hobi/minat/bakat, menemukan passion, menghadapi tantangan.
Pengalaman kepemimpinan seperti: pengalaman pertama dengan isu politik dan kewarganegaraan, momen penting dalam pekerjaan, tokoh panutan dalam komunitas, konflik antara diri sendiri dan komunitas, berbeda pandangan politik dengan keluarga.

\section{3) Spesifik.}

Cerita harus spesifik dan benar-benar menggambarkan kejadiannya seperti tempatnya, waktunya, siapa yang terlibat, apa konfliknya, bagaimana cara mengatasinya dan apa yang terjadi. Sehingga saat pendengar mendengarkan cerita tersebut memahami secara mendalam.

\section{4) Sederhana.}

Cerita tidak harus panjang namun sederhana, mudah dipahami dan penuh makna.

\section{5) Lucu, tetapi maknanya dalam.}

Untuk menghilangkan kebosanan pendengar bisa menyisipkan candaan dari peserta supaya mereka tetap fokus pada cerita kita.

6) Mengikuti kerangka dramatis .

Buat kerangka cerita dengan menggunakan alur ada awalan, isi dan penutup.

7) Bercerita dari hati, bukan menghafal.

Bercerita kejadian yang dialami sendiri merupakan cerita yang dari hati. Emosi yang ada seperti bahagia, takut, sedih terkejut pasti akan terulang kembali saat membawakan cerita.

8) Hadir bersama penonton.

Libatkan penonton dalam cerita yang kamu sajikan. Anggap keberadaannya ia ada dengan menatapnya, 
melemparkan pertanyaan atau ajak interaksi.

\section{Cara mengetahui cerita yang hebat}

1) Ceritanya harus berarti/memiliki makna,

2) Ceritanya harus memiliki konflik,

3) Ceritanya harus tentang kehidupan, bukan cerita tentang seluruh hidupmu.

4) Ceritanya harus jujur,

5) Kekuatan ceritanya ada pada "koneksi"

6) Cerita harus menggambarkan keadaan - suara, bau, perasaan, cuaca.

7) Ceritanya harus mengungkapkan sesuatu.

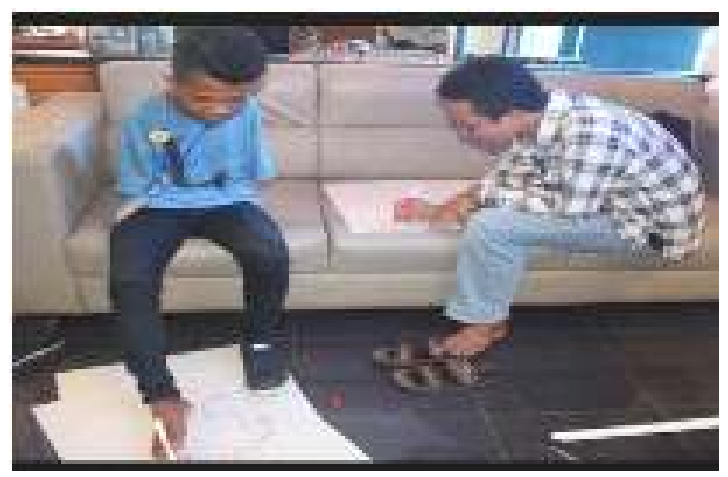

Gambar 3. Membuar Cerita

\section{B. Alur Cerita}

\section{Tantangan}

Dalam kehidupan tentu banyak tantangan yang kita hadapi, baik yang hubungannya diri sendiri komunitas, kelurga dan lainnya. Pilihlah tantangan yang kiranya cocok akan kamu bagikan kepada pendengar. Harapannya dari cerita tersebut pendangar menjadikan sebagai referensi dalam penyelesaian tantangan. Misalnya tantangan hidup dikalangan minoritas, tinggal serumah dengan mertua, nikah beda adat dan lainnya.

\section{Pilihan}

Kemukakan apa pilihan anda dari tantangan yang kalian hadapi, kenapa kamu memilih yang ini, dan tidak itu, apa reaksi sekelilingnmu jika kamu memilih yang ini dan menolak yang itu, serta apa yang melatarbelakangi serta dampak dari pilihanmu tersebut .

\section{Keluaran/Hasil}

Identifikasi cerita anda dengan membuat pertanyaan, apa hasil dari pilihan kamu? Bagaimana dampaknya? dan selanjutnya apa yang kamu lakukan?

\section{Nilai}

Nilai apa yang telah kamu transfer dari cerita tersebut? Darimana nilai tersebut datang? Bagaimana nilai itu dating? Dan bagaimana perasaan orang lain dari nilai cerita anda?

\section{Panduan teknis bercerita}

Pelaksanaan bercerita dilakukan secara berpasangan oleh dua orang. Setiap peserta bercerita sesuai panduan dengan durasi maksimal 2 menit. Setelah keduanya bercerita secara mandiri, tugas selanjutnya membuat cerita gabungan dari kedua peserta dengan tambahan berbagai metode. Dapat dilakukan dengan drama, puisi, pantun, atau lagu.

\section{Publikasi Cerita}

Luaran dari kegiatan pengabdian ini adalah terbentuknya cerita yang diupload melalui peta cerita dengan alamat website https:/petacerita.id. Peta cerita dalam profilnya menjelaskan bahwa Community Empowerment for Raising Inclusivity and Trust through Technology Application, or CERITA (which means "story" in Bahasa Indonesia), uses the 
art of storytelling to fight discrimination, promote inclusivity and build trust among different elements of the society. The pilot phase reached 150 young influencers in five Indonesian cities, training them to act as facilitators and storytellers in their own communities. A project from The Habibie Center, and supported by Google Foundation of Tides Foundations, CERITA launched in April of 2017 in five major cities: Jakarta, Bandung, Malang, Solo, and
(Halaman 29-36)

Peserta dalam mengupload video cerita, diwajibkan untuk memberikan tanda nama kota cerita tersebut dibuat. Saat mereka bepergian, kuliah atau kerja diberbagai kota dapat membuat cerita lalu menyimpannya dipeta cerita. Harapannya akan tersebar banyak cerita diberbagai kota di Indonesia. Sehingga konflik karena keberagaman dapat diminimalisir dari video tersebut.

Yogyakarta.

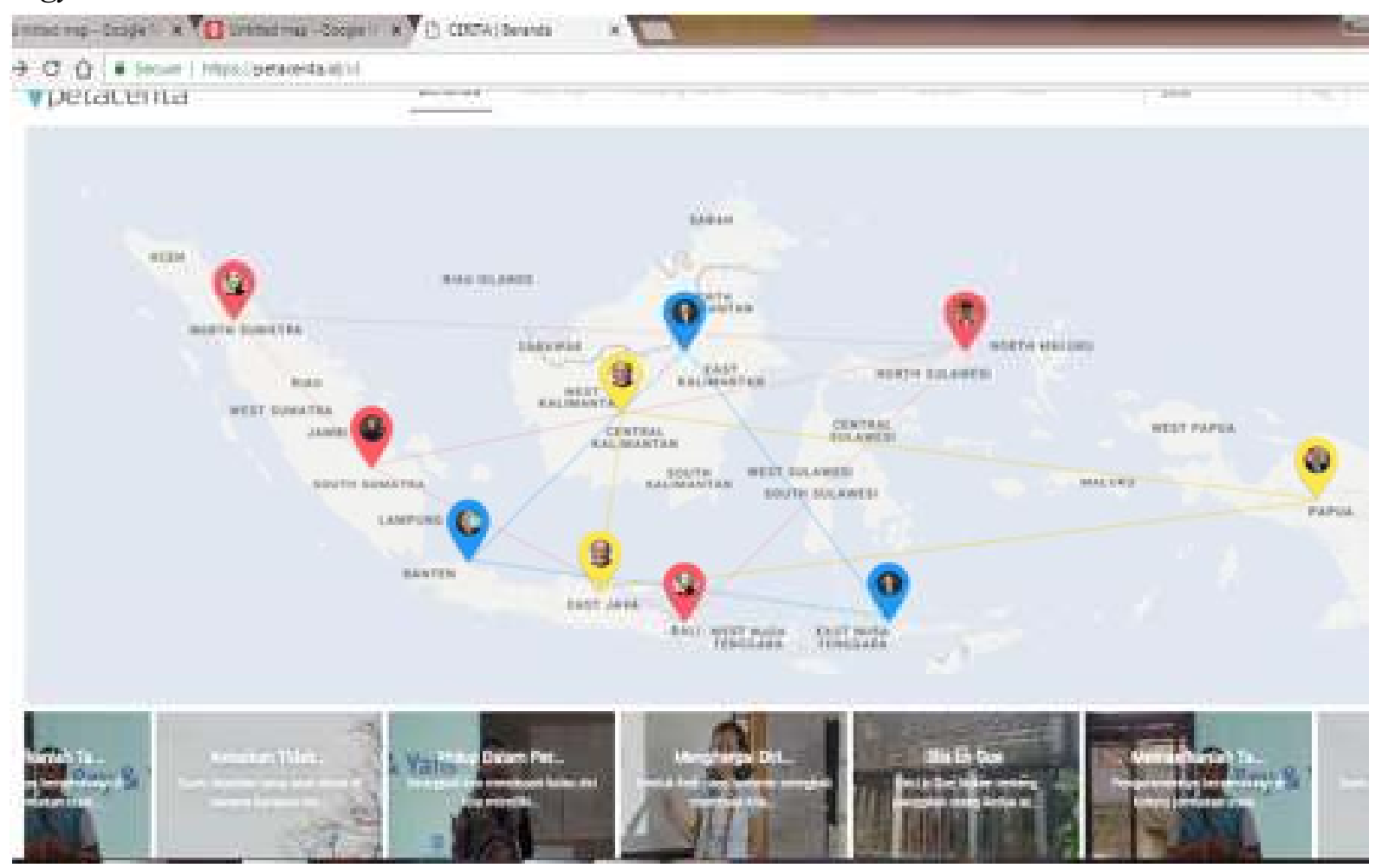

Gambar 4. Peta Cerita

Menanggapi tentang keberagaman Toto Suryana (2011) menyatakan bahwa keberagaman sudah merupakan ketentuan Tuhan Yang Maha Esa, maka diperlukan sikap berterima kasih dan ada usaha untuk memelihara dengan mengarahkannya kepada kepentingan dan tujuan bersama. Pluralisme dan multikultural merupakan ciri masyarakat Indonesia. Makanya yang dibutuhkan adalah sikap toleransi dan sanggung hidup dalam perbedaan. Menerima keanekaragaman dengan lapang dada, menghomati hak pribadi dan sosial pihak yang berbeda menjalani kehidupan mereka.

\section{PENUTUP}

Hasil dari kegiatan pengabdian masyarakat ini adalah terbentuknya cerita 
dengan berbagai keberagaman dalam rangka meningkatkan toleransi dan keberagaman. Adapun hasil cerita diunggah melalui peta cerita. Saran bagi pengabdi yang lain adalah dapat meneruskan program ini dalam skala yang besar dengan berbagai keberagaman yang besar pula.

\section{DAFTAR R U J U KAN}

Republik Indonesia. 2016. Toleransi di daerah rawan konflik. Kementrian Agama Republik Indonesia: Jakarta.

Toto Suryana. 2011. Konsep dan Aktualisasi kerukunan antar umat beragama. Jurnal Pendidikan Agama Islam. Ta'lim Vol. No. 2.
Mukti Ali. 2006. Pluralisme Agama di Persimpangan Menuju Tuhan, (Salatiga: STAIN Salatiga Press.

Ali, H. Mukti. 1975. Kehidupan Beragama Dalam Proses Pembangunan Bangsa. Bandung.

Zakiyuddin Baidhawi. 2005. Proyek Pembinaan Mental Agama, Pendidikan Agama Berwawasan Multikultural. Jakarta: Erlangga.

http://nasional.kompas.com/read/2017/01 /05/18280081/catatan.komnas.ham .kasus.

intoleransi.meningkat.setiap.tahu n.

https://www.bps.go.id/news/2015/11/18/1 27/menguli k-data-suku-diindonesia.html. 